\title{
KUALITAS IKAN CAKALANG (Katsuwonus pelamis L.) ASAP PADA BEBERAPA SENTRAL PENGOLAHAN DI SULAWESI UTARA
}

\author{
Agatha I. N. Landangkasiang', Nurmeilita Taher², Josefa Kaparang² \\ ${ }^{1)}$ Mahasiswa pada Program Studi Teknologi Hasil Perikanan FPIK Unsrat Manado \\ ${ }^{2)}$ Staf pengajar pada Program Studi Teknologi Hasil Perikanan FPIK Unsrat Manado
}

\begin{abstract}
ABSTRAK
Ikan Cakalang $f u f u$ merupakan ikan asap khas Sulawesi Utara termasuk produk khas yang semakin digemari dan diminati oleh konsumen baik lokal maupun internasional, sehingga menjadi wisata kuliner atau sebagai souvenir khas Sulawesi Utara. Metode tradisional pengawetan makanan dengan pengasapan biasanya menghasilkan garam tinggi, dan produk dengan kadar air rendah yang tidak diinginkan oleh pasar modern. Oleh karena itu, produsen menyesuaikan kondisi pemprosesan untuk menghasilkan produk ikan asap dengan kelembaban yang lebih rendah yang akan dijual ke pasar sekarang ini. Tujuan penelitian ini adalah untuk mengetahui kualitas ikan cakalang asap yang ada di 5 tempat pengolahan di Sulawesi Utara dan manfaatnya dapat memberikan informasi kepada semua pihak yang terkait dalam pengolahan ikan cakalang asap, baik sebagai produsen maupun sebagai konsumen tentang kualitas ikan cakalang asap yang terkandung di setiap sampel sesuai atau tidak sesuai berdasarkan Standarisasi Nasional Indonesia. Hasil uji kadar garam, air dan organoleptik menunjukkan bahwa sampel ikan cakalang asap yang berasal dari 5 tempat pengolah di Sulawesi Utara masih memenuhi Standar Nasional Indonesia dengan kualitas yang baik.
\end{abstract}

Kata Kunci: Ikan Cakalang Asap, Analisa Kadar Garam, Analisa Kadar Air, Organoleptik.

\section{PENDAHULUAN}

Pengawetan ikan dengan pengasapan sudah lama dilakukan manusia. Teknologi pengasapan termasuk cara pengawetan ikan yang telah diterapkan secara turun temurun. Istilah pengasapan (smoking) diartikan untuk penyerapan bermacam-macam senyawa kimia yang berasal dari asap kayu ke dalam daging ikan, disertai dengan setengah pengeringan dan biasanya didahului dengan proses penggaraman (Sulistijowati, 2011).

Ikan cakalang fufu merupakan ikan asap

khas Sulawesi Utara termasuk khas produk yang semakin digemari dan diminati oleh konsumen baik lokal maupun internasional, sehingga menjadi wisata kuliner atau sebagai souvenir khas Sulawesi Utara. Pengolahan ikan cakalang asap di Sulawesi Utara umumnya masih dilakukan secara tradisional atau pengolahan dilakukan secara turun temurun. Ikan fufu menjadi awet karena adanya pengurangan kadar air akibat dari proses pemanasan dan adanya senyawa-senyawa kimia di dalam asap seperti golongan fenol yang dapat menghambat pertumbuhan mikroorganisme dan berperan sebagai antioksidan, walaupun begitu pengasapan ikan pada saat ini dilakukan dengan tujuan untuk memberikan warna, tekstur dan flavor yang khas (Bligh et al. 1988; Martinez et al. 2007)

\section{METODOLOGI PENELITIAN}

Metode yang digunakan dalam penelitian ini adalah metode deskriptif yaitu mengumpulkan data di lapangan melalui pengamatan secara terperinci kemudian dilakukan analisa data kualitatif.

\section{Tempat dan Waktu Penelitian}

Penelitian ini dilaksanakan di Laboratorium Pengendalian Mutu Hasil Perikanan, Program Studi Teknologi Hasil Perikanan Universitas Sam Ratulangi Manado. Waktu pelaksanaan penelitian selama 5 bulan sejak bulan Januari sampai Mei 2017.

\section{Alat dan Bahan \\ Alat yang digunakan dalam penelitian ini diantaranya, timbangan analitik dengan kepekaan minimum $1 \mathrm{mg}$, erlenmeyer $250 \mathrm{ml}$, pipet volumetrik $15 \mathrm{ml}$ dan $25 \mathrm{ml}$, pipet tetes, pipet ukur $10 \mathrm{ml}$, hot plate, buret $50 \mathrm{ml}$, cawan porselen, oven, desikator, tissue, plastik. \\ Bahan yang digunakan dalam penelitian ini diantaranya, ikan cakalang (Katsuwonus Pelamis L.), Akuades, larutan perak nitrat 0,1}


M, larutan potasium thiosianat $0,1 \mathrm{M}$, larutan ammonium feri sulfat jenuh, larutan nitrat pekat $(70 \%)$, larutan potasium permanganat, larutan kalium kromat.

\section{Tata Laksana Penelitian Tahapan Penelitian}

Sampel ikan cakalang asap sebanyak 5 jepit diambil dari 5 tempat pengolah ikan asap di Sulawesi Utara yaitu Bitung, Manado, Tanawangko, Amurang, Paslaten. Selanjutnya, sampel dimasukan dalam plastik, kemudian dibawa ke Laboratorium Penanganan dan Pengendalian Mutu Hasil Perikanan untuk dilakukan analisis.

Analisa yang dilakukan meliputi pengujian kadar garam dengan metode volhard, kadar air menggunakan metode oven dan pengujian organoleptik dengan menggunakan pendekatan interval.

\section{HASIL DAN PEMBAHASAN}

\section{Proses Pengolahan Ikan Asap Pada 5 Sentral Pengolahan}

Dari hasil pengamatan di lapangan, diperoleh informasi tahapan pengolahan dari ke 5 sentral pengolahan, seperti pada tabel di bawah ini.

Tabel 1. Tahapan Pengolahan Pada 5 Sentral Pengolahan Ikan Asap.

\begin{tabular}{|c|c|c|c|c|c|}
\hline & 兽 & 宽 & 易 & 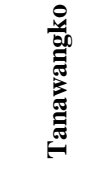 & 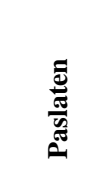 \\
\hline $\begin{array}{c}\text { Asal } \\
\text { Bahan } \\
\text { Baku }\end{array}$ & Perusahaan & $\begin{array}{c}\text { TPI } \\
\text { Bitung } \\
\& \\
\text { Manado }\end{array}$ & $\begin{array}{c}\text { TPI } \\
\text { Manado }\end{array}$ & $\begin{array}{c}\text { TPI } \\
\text { Manado }\end{array}$ & $\begin{array}{c}\text { TPI } \\
\text { Manado }\end{array}$ \\
\hline $\begin{array}{l}\text { Peren- } \\
\text { daman }\end{array}$ & $\begin{array}{l}\text { Larutan } \\
\text { Garam } \\
\text { (2 Jam) }\end{array}$ & - & $\begin{array}{l}\text { Air Laut } \\
\text { Dingin } \\
(2 \text { jam })\end{array}$ & - & - \\
\hline $\begin{array}{l}\text { Penge- } \\
\text { ringan }\end{array}$ & $\begin{array}{c} \pm 1 \\
\text { Jam }\end{array}$ & $\begin{array}{c} \pm 1 \\
\text { Jam }\end{array}$ & $\begin{array}{c} \pm 1 \\
\text { Jam }\end{array}$ & $\begin{array}{c} \pm 1 \\
\text { Jam }\end{array}$ & $\begin{array}{c} \pm 1 \\
\text { Jam }\end{array}$ \\
\hline $\begin{array}{l}\text { Penga- } \\
\text { sapan }\end{array}$ & $\begin{array}{c}5 \\
\text { jam }\end{array}$ & $\begin{array}{c}5 \\
\text { jam }\end{array}$ & $\begin{array}{l}3-5 \\
\text { jam }\end{array}$ & $\begin{array}{l}3-5 \\
\text { jam }\end{array}$ & $\begin{array}{l}3-5 \\
\text { jam }\end{array}$ \\
\hline $\begin{array}{l}\text { Pendi- } \\
\text { nginan- } \\
\text { Penge- } \\
\text { masan }\end{array}$ & $\begin{array}{l}1-2 \\
\text { jam }\end{array}$ & $\begin{array}{l}1-2 \\
\text { jam }\end{array}$ & $\begin{array}{l}1-2 \\
\text { jam }\end{array}$ & $\begin{array}{c}1 \\
\text { jam }\end{array}$ & $\begin{array}{l}2-3 \\
\text { jam }\end{array}$ \\
\hline $\begin{array}{c}\text { Pewar- } \\
\text { na }\end{array}$ & - & - & $\begin{array}{c}\text { Pewarna } \\
\text { Kue }\end{array}$ & - & $\begin{array}{c}\text { Pewarna } \\
\text { Kue }\end{array}$ \\
\hline
\end{tabular}

Maka dari tabel 1 di atas diperoleh data, setiap tahapan pada proses pengolahan ikan asap dari 5 sentral pengolahan hampir sama. Dari kelima sentral pengolahan ikan asap, terdapat 2 tempat yang memiliki perlakuan khusus pada bahan baku ikan dengan perlakuan perendaman pada larutan garam dan air laut dingin yaitu Bitung dan Amurang. Untuk proses pengeringan sampai pendinginan/pengemasan setiap sentral pengolahan rata-rata memiliki waktu yang sama yaitu sekitar 3-5 jam.

\section{Analisa Kadar Garam}

Dari hasil keseluruhan nilai kadar garam yang diperoleh pada sentral pengolahan ikan asap, walaupun ada yang memiliki nilai kadar garam paling tinggi, tapi pada umumnya masih memenuhi persyaratan mutu dan keamanan pangan hasil perikanan khususnya pada kadar garam yaitu maksimal $4 \%$ dalam SNI.

Garam merupakan komponen kimia yang bersifat bakteriostatik maupun bakteriosidal. Bakteri mampu dibunuh oleh garam oleh karena sifatnya higroskopis sehingga mampu menyerap air (sitoplasma) bakteri pada akhirnya sel bakteri mengkerut dan mati (Salosa, 2013). Histogram hasil uji kadar garam dapat dilihat pada Gambar 1 berikut.

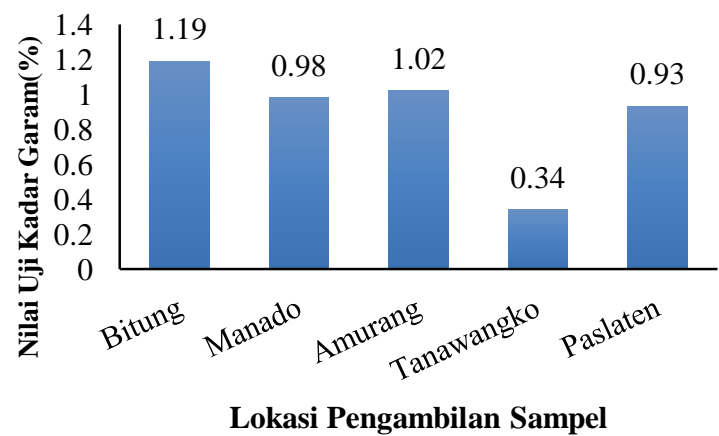

\section{Gambar 1. Nilai Uji Kadar Garam Ikan Cakalang (Katsuwonus pelamis L.) Asap Berdasarkan Asal Sampel.}

\section{Analisa Kadar Air}

Dari hasil penelitian diperoleh data bahwa sampel ikan asap yang berasal dari 5 sentral pengolahan di Sulawesi Utara masih memenuhi batas standar nilai kadar air pada produk perikanan sesuai dengan SNI.

Perubahan kadar air pada proses pengasapan diakibatkan karena panas dan penarikan air dari jaringan tubuh ikan oleh penyerapan berbagai senyawa kimia dari asap (Wibowo, 2000). Harikedua (1995) menyatakan bahwa suhu dan lama pengasapan mempengaruhi nilai kadar air, hal ini dikarenakan selama proses pengasapan berlangsung terjadi penguapan molekul-molekul air dari produk yang diasapi. 


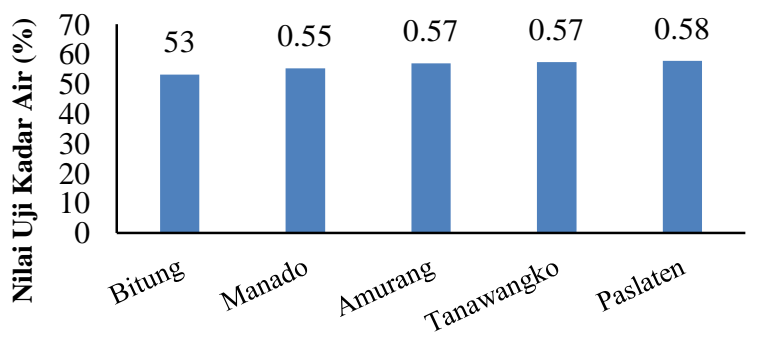

Lokasi Pengambilan Sampel

Gambar 2. Nilai Uji Kadar Air Ikan Cakalang (Katsuwonus pelamis L.) Asap Berdasarkan Asal Sampel.

\section{Uji Organoleptik}

Dari gambar di atas diperoleh data yaitu sampel yang memiliki rasa asin yang paling tinggi sesuai penilaian panelis adalah sampel ikan asap dari Amurang dengan nilai 41,7, sedangkan untuk sampel yang memiliki rasa asin paling rendah yaitu ikan asap yang berasal dari Paslaten dengan nilai 35,3. Gambar di atas juga menunjukkan sampel ikan asap yang berasal dari Manado memiliki tekstur yang kurang lebih pas untuk dikunyah dengan nilai berkisar 58,3, sedangkan sampel yang berasal dari Bitung memiliki tekstur yang agak lunak tetapi masih bisa dikunyah dengan nilai yang berkisar pada 39,8 .

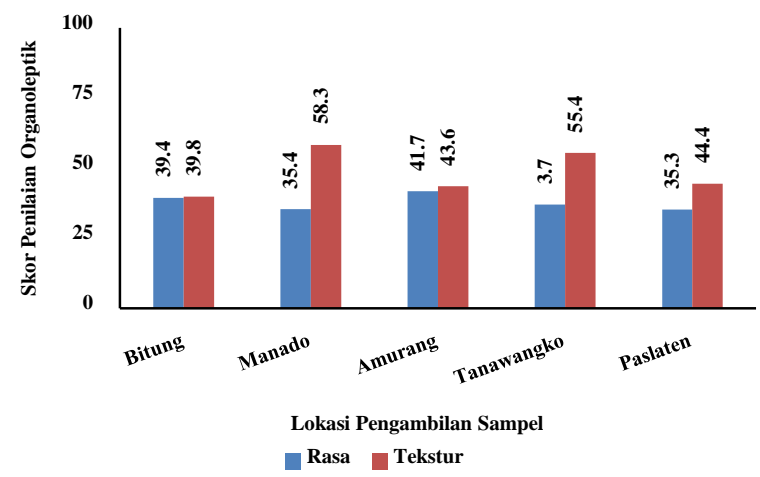

Gambar 3. Nilai Organoleptik Ikan Cakalang (Katsuwonus pelamis L.) Asap Berdasarkan Asal Sampel.

\section{Hubungan Hasil Uji Kadar Garam dengan} Uji Organoleptik Rasa

Berdasarkan nilai $r(0,1312)$ yang diperoleh, maka diketahui ada korelasi antara kadar garam dengan organoleptik rasa, yaitu semakin besar hasil uji kadar garam maka uji organoleptik rasa cenderung lebih kuat. Ini disebabkan karena garam sebagai pembangkit aroma dan cita rasa serta penstabil warna daging ikan mempunyai fungsi dan peranan penting dalam proses preparasi dan pengolahan pangan (Yankah et al., 1996; Pszczola, 1997). Cita rasa suatu pro- duk biasanya merupakan gabungan dari tiga komponen, yaitu aroma, rasa dan rangsangan mulut (Zuhra, 2006).

\section{Hubungan Hasil Uji Kadar Air dengan Uji Organoleptik Tekstur.}

Berdasarkan nilai $r(0,1878)$ yang diperoleh, maka diketahui ada korelasi antara kadar air dengan organoleptik tekstur, yaitu semakin rendah kadar air yang terkandung pada ikan asap maka uji organoleptik rasa cenderung lebih tinggi. Fenomena ini juga didukung oleh hasil penelitian Enampato (2011) yang menyatakan bahwa semakin rendah jumlah kadar air pada produk ikan asap kering maka nilai teksturnya semakin tinggi.

\section{KESIMPULAN DAN SARAN}

\section{Kesimpulan}

1. Kadar Garam pada 5 sampel ikan asap dari beberapa tempat di Sulawesi Utara yang berasal dari Bitung, Manado, Tanawangko, Amurang dan Tomohon masih pada batas wajar dan memenuhi Standar Nasional Indonesia tentang penggunaan garam pada produk perikanan yaitu maksimal $4 \%$, dilihat dari analisa data dengan menggunakan metode volhard.

2. Kadar air pada 5 sampel ikan asap dari beberapa tempat di Sulawesi Utara yang berasal dari Bitung, Manado, Tanawangko, Amurang dan Tomohon memenuhi standar sesuai dengan Standar Nasional Indonesia tentang Persyaratan Mutu dan Keamanan Pangan yaitu maksimal $60 \%$.

3. Uji Organoleptik menunjukkan bahwa rasa asin pada ikan asap masih rendah sesuai dengan data rata-rata keseluruhan dari 30 panelis yang ada pada 5 sampel ikan asap, dan tekstur ikan asap dari data rata-rata keseluruhan dari 30 panelis terhadap 5 sampel ikan asap masih pada batas masih mudah untuk dikunyah.

\section{Saran}

Perlu mempertahankan proses pengolahan yang baik pada setiap sentral pengolahan ikan asap, agar produk yang dihasilkan tetap memenuhi Standar Nasional Indonesia.

\section{DAFTAR PUSTAKA}

Bligh E.G, Shaw SJ, Woyewoda A.D. 1988. Effect of drying and smoking on Lipids of fish. Di dalam: Burt 
JR, editor. Fish Smoking and Drying. New York: Elsevier Science Publishers Ltd. p: 41-52.

Enampato, M.H. 2011. Inventarisasi Keragaman Mutu Produk Ikan Tandipang (Dussumieria acuta C.V.) Asap Kering Produksi Rumah Tangga Di Desa Matani I Kecamatan Tumpaan. Skripsi. Fakultas Perikanan dan Ilmu Kelautan. UNSRAT. Manado.

Harikedua, J.W. 1995. Pengantar Teknologi Hasil Perikanan. Materi Kuliah. Fakultas Perikanan dan Ilmu Kelautan. Universitas Sam Ratulangi Manado.

Pszczola, D.E. 1997. Salt developments in food. Food Technology. 51 (2): 79-90.
Salosa, Y. 2013. Uji kadar formalin, kadar garam dan total bakteri ikan asin tenggiri asal Kabupaten Sarmi Provinsi Papua. Fakultas Matematika dan Ilmu Pengetahuan Alam, Universitas Negeri Papua.

Sulistijowati, Rieny S., 2011. Mekanisme Pengasapan Ikan. UNPAD Press. Diakses 10 Februari 2017, dari mekanisme-pengasapan-ikan.pdf

Wibowo, S. 2000. Industri Pemindangan Ikan. Penebar Swadaya. Jakarta.

Zuhra, C.F. 2006. Flavor (Citarasa). Departemen Kimia, Fakultas Matematika dan Ilmu Pengetahuan Alam, Universitas Sumatera Utara. 32 hal. 